\title{
Reviving farming interest in the Philippines through agricultural entrepreneurship education
}

\author{
Andrea Santiago a* \\ De La Salle University \\ Fernando Roxas ${ }^{b}$ \\ Asian Institute of Management
}

Submitted July 20, 2014 / Revised September 15 and December 26, 2014, and January 25, 2015 /

Accepted May 1, 2015 / Published online August 25, 2015

Citation: Santiago, A., \& Roxas, F. (2015). Reviving farming interest in the Philippines through agricultural entrepreneurship education. Journal of Agriculture, Food Systems, and Community Development, 5(4), 15-27. http://dx.doi.org/10.5304/jafscd.2015.054.016

Copyright (C) 2015 by New Leaf Associates, Inc.

\begin{abstract}
There is a need to entice a new generation of Filipinos to practice value-added agriculture to replace the current farmers expected to retire in a decade or so. But persistent poverty levels in agricultural areas have dissuaded Filipino youth from pursuing opportunities in this sector. In this commentary, we propose that the Philippine government work with private investors and sociocivic organizations to revive interest in agriculture by positioning it as an attractive and viable option.

a * Corresponding author: Andrea Santiago, Professor, Management and Organization Department, De La Salle University; 2401 Taft Avenue; Manila, Philippines 1004; ma.andrea.santiago@dlsu.edu.ph

b Fernando Roxas, Associate Professor, Asian Institute of Management, Washington Sycip Graduate School of Business, Asian Institute of Management; 123 Paseo de Roxas; Makati, Philippines; fyanroxas@aim.edu
\end{abstract}

This can be done by stimulating entrepreneurial activities in agriculture, through targeted agricultural entrepreneurship education. Entrepreneurship shifts attention from producing more of the same things to producing value-added goods and services through managed agricultural risks. To encourage opportunity seeking and value creation in this sector, there is need to train current farmers to become more entrepreneurial and to educate future generations to become agricultural entrepreneurs. This commentary presents four current strategies to increase interest in agricultural entrepreneurship in the Philippines-Family Farm Schools, the SAKA program, Farm Business Schools, and the Social Enterprise approach of Gawad Kalinga. Clearly, a more concerted effort among government, socio-civic organizations, and private investors is needed for substantial outcomes to materialize. 


\section{Keywords}

rural education, agricultural entrepreneurship, agripreneurship, agribusiness, farming, Philippines

\section{Introduction}

Eradication of poverty is part of the main agenda of international and multilateral organizations, such as the Asian Development Bank, the Food and Agriculture Organization of the United Nations, and the World Bank (UN, 2013). The UN claims that to eradicate poverty, economic growth must be inclusive; that is, the benefits of economic growth are shared among all sectors of society, so that no sector is left behind (Islam, 2004). The fact that poverty persists especially in the countryside in some developing countries, despite reported economic growth, may mean that growth has not been inclusive (Hull, 2009).

Karnani (2007) states that the only way to truly help the poor is to increase their real income. This is to beachieved by reducing the price of goods and services that they purchase, increasing their earning capacity, or-ideally-both. One way to increase earning capacity is to move towards a cycle of growth, employment, and poverty reduction through encouraging entrepreneurial activity (Islam, 2004). A healthy entrepreneurial environment means more jobs, greater purchasing power, higher tax contributions, and better community service delivery. Consequently, it makes sense for developing countries interested in inclusive growth to create structures that support entrepreneurial activity (Acs \& Szerb, 2007).

There is general acceptance that entrepreneurial activity spurs economic growth, although not all agree as to whether it encompasses all forms of activity (including self-employment, rent, and job creation) or only those that introduce innovation in products, services, processes, or delivery (Busenitz, Gomez, \& Spencer, 2000; van Stel, Carree, \& Thurik, 2005; Williams \& McGuire 2010). In the absence of a universal definition or measurement, we favor the theory that any entrepreneurial activity spurs the economy. This is because we believe entrepreneurship creates jobs. If developing economies provide livelihood opportunities that bridge the income divide, then government should support entrepreneurial activities, particularly in last mile rural areas. Lamb and Sherman (2010) are optimistic that with proper support rural areas can become more productive.

\section{In Support of Agricultural Entrepreneurship}

The Philippines is still considered an agricultural country; yet the average age of farmers is 57 years (Pangilinan, cited in Casauay, 2014). This suggests that in a decade or so, there will be no more Filipino farmers unless a youthful generation replaces them. Unfortunately, children of farmers take no interest after seeing their parents remain in poverty (Cariño, 2013)

Farmers, fishermen, and foresters are among the poorest citizens of the Philippines. They pay more for basic services and commodities than those who have the capacity to pay, because investment costs to extend electricity lines escalate the farther the lines are from the electricity grid (Mendoza, 2011). They often have to borrow from micro-financiers and repay the loan in weekly installments; they end up paying higher interest charges as compared to bank rates (Carroll, 2010). The focus on short-term credit is counterproductive, since the farmers prioritize survival needs before loan repayments. Longer gestation crops need longer repayment periods because farmers cannot generate income to pay the loan until they are able to sell their harvest (Audinet \& Haralambous, 2005). Typically, farmers cultivate small farm lands, averaging 1.5 hectares, which makes them more vulnerable to the effects of climate change as well as to forces brought about by economic liberalization (Kahan, 2007).

Trade liberalization has opened new markets for farmers but tends to favor commercial farms (Kahan, 2007), presenting more challenges to the greater number of farmers who own smaller portions of land (von Braun \& Diaz-Bonilla, 2008). Since the farmers are at a disadvantage, it is no surprise that hunger persists even if they grow food on their farms. To survive, farmers will have to be more equipped to compete or they will have to band together to enjoy the advantages of large farms. This initiative should go beyond contractgrowing agreements, where large companies provide guaranteed purchase of produce provided certain standards are met. Under such contracts, 
farmers bear all the production risks even if they gain only small margins. It thus makes sense for farmers to integrate forward, alone or in partnership with entrepreneurs, and become agricultural entrepreneurs.

Smit (cited in Richards \& Bulkley, 2007) believes that entrepreneurship should be at the core of farming. If a farm can be considered a firm, and the farmer the owner, then certainly the farmer must be equipped with entrepreneurial skills to manage the farm profitably and to surmount the challenges faced by the agricultural sector. We refer to these special skills as agripreneurial skills, while we label the farmer turned entrepreneur as the agricultural entrepreneur or agripreneur. We provide new terminology for ease in referencing, as the generic terms of entrepreneur, entrepreneurial, and entrepreneurship are usually associated with industrial or non-farm activity (Richards \& Bulkley, 2007; Singh \& Krishna, 1994). We also need to differentiate the farmer and farm manager from the agripreneur. A farmer is concerned with cultivating land, a farm manager oversees farm operations, but an agripreneur finds opportunities to make the most of agricultural output.

Following the proposition that increased entrepreneurial activity can break the poverty cycle, we expect that the rise of agripreneurs will improve the standard of living of the rural poor. This debunks the common misconception of youth that farming is a poor person's job. When agripreneurs are able to utilize business processes and resources to convert agricultural commodities into highermargin products, they can compete even in the export market. Value creation at the farm level stimulates greater farm production, bringing more income to the agripreneurs. Improving the purchasing power of agripreneurs and farmers makes them a viable consumer market base, thus further stimulating economic activity (Timmer, 2005). An ideal outcome of agripreneurship education would be the stabilization of rural populations, numbers of farms, and farm acreage under production.

An aditional benefit might also include less congestion in urban areas: currently, rural dwellers abandon farmlands in favor of employment in urban cities to obtain predictable income streams (McElwee \& Annibal, 2009). The migration toward urban areas is a phenomenon typical of many developing countries, the Philippines included. Urban migration places a strain on resources which have to be diverted to addressing the ills of densely populated areas, such as increasing criminality and unsanitary conditions (Tacoli, 2011). The attraction of moving to the cities has also led to young people leaving the farms they grew up on, leaving the tilling of the soil to the older generation, who have no one to pass the farms to. Some farmers near cities are able to sell their land to investors who convert the land to non-agricultural uses (Vallianatos, Gottlieb, \& Haase, 2004), but the rest simply cultivate their farms for subsistence purposes alone. Consequently, there are fewer agricultural producers feeding a growing population. It is said that developing countries would need to almost double their agricultural production to meet their population levels in 2050 (FAO cited in AMIS, 2011). Together with increased productivity, improving farm incomes through entrepreneurial means contributes to the economic sustainability of agricultural communities.

Since the economy of many developing countries is agriculture-based, we believe that various sectors in society should collaborate in a more focused manner to arrest urban migration. This collaboration is possible by supporting agricultural entrepreneurship (or agripreneurship) education. Beyond farming and farm management training, emphasis should be given to the entrepreneurship side, providing skills related to opportunity seeking, value creation, risk management, resource generation, and commercialization, among others (Knudson, Wysocki, Champagne, \& Peterson, 2004; O’Neill, Hershauer, \& Golden, 2009). With more individuals exposed to agripreneurship, developing countries can generate more agripreneurs, who will be able to create more value for their produce.

\section{The Case of the Philippines}

Moves by the Philippine government to support agripreneurship are timely. Despite efforts to increase farm productivity, crop production from 13 milion hectares of land grew marginally from 87 million in 2011 to 88 million metric tons in 2012. Despite the increase in output, crop production in 
2012 was valued at P797 million, down from P802 million in 2011 (Philippine Statistics Authority [PSA], 2013). Even for rice, a basic staple of Filipinos, unmilled rice production reached only 18 million metric tons, resulting in only 11 million metric tons of rice. Assuming an average annual consumption of 115 kilograms per person, the Department of Agriculture estimates that production should reach at least 20 million metric tons to feed close to 100 million people (Cai, 2013). The difference between what is milled and what is needed for consumption has been covered so far by importation. Milled rice is imported primarily from Vietnam, which produces rice at a small fraction of Filipino rice production cost (Bordey \& Litonjua, 2013).

The Department of Agriculture has boldly promised that the Philippines will be self-sufficient in rice, but continued exposure to natural disasters threatens this goal, even assuming that rice selfsufficency is an efficient economic policy (Fernandez-San Valentin \& Berja, 2012). Indeed, climate change has not made it easy on Filipino farmers, who have to contend with hotter dry seasons and wetter rainy seasons, even in areas previously unaffected by unpredictable weather conditions. Efforts continue to enhance agricultural as well as fisheries productivity, however. Enabling laws have been enacted to introduce reform in agriculture, such as the Organic Agricultural Act of 2010 and the Agriculture and Agrarian Reform Credit and Financing System through Banking Institutions. known as the Agri-Agra Reform Credit Act of 2009. Despite the law compelling banks to allocate ten percent of their loan portfolio to the agricultural sector, the Philippine Central Bank reports that there is a huge shortfall in lending, forcing banks to comply with their legal mandate by channeling funds to infrastructure projects in the agricultural sector (Martin, 2014).

We believe that one of the main causes of the failure of government initiatives to grow the agriculture sector has been the focus on productivity rather than on entrepreneurial activity. Investments in better technology, improved irrigation systems, disaster-resistant crop species, and even in better farm-to-market roads will not result in expected outcomes if the farmers remain focused only on land cultivation. While agricultural productivity is important, training programs must emphasize the development of entrepreneurial qualities. We believe farmers and their next generation kin need to be equipped not only with farming skills but, more importantly, with entrepreneurial skills. This allows a shift from producing more of the same crops to selling value-added produce.

It is encouraging that the Philippines Department of Agriculture has finally recognized the importance of agripreneurship, as embodied in the Philippine Agriculture (PA) 2020 plan. This strategic plan aims to have a "farmer-focused, marketdriven agriculture that attempts to transform traditional small farmers into entrepreneurs" (Santiago, 2014). With this aim clearly in place, we are hopeful that other government agencies and lending institutions will give Filipino agripreneurs a fighting chance to rise above poverty.

\section{Addressing the Gap with Education}

Education plays a critical role in changing mindsets. For the PA 2020 plan to be achieved, the formal education system will need to emphasize the relevance of agricultural entrepreneurship. In the Philippine education system, the Department of Education supervises basic education, the Technical Education and Skills Development Authority supervises technical and vocational training, and the Commission on Higher Education supervises higher education. A problem with the basic education sysyem is that for decades it has focused on preparing students for college. This emphasis is to encourage students to take the route of higher education to improve their employability. Unfortunately, not all college graduates are able to obtain employment in their field of study (Rosero, 2013). Often they are overqualified for available jobs. This is one of the reasons why the Department of Education has adopted a 12 -year basic education program, beginning with the academic year 20122013, which introduced a two-year senior high school program that allows high school students to choose tracks other than college preparation (Okabe, 2013).

For this analysis, we focused on two tracks introduced by the Department of Education in the 
12-year program: a technical-vocational livelihood track in agricrop, animal and fish production; and an entrepreneurship track. For agricultural entrepreneurship to work, the two tracks should be combined. In this way, hard technical know-how can be combined with innovative and entrepreneurial skills. Graduates would be familiar with the challenges of agricultural production as well business skills. Thus the learning curve of bring goods from farm to market is shortened. Unfortunately, the two tracks are separate in the Department of Education curriculum, with the agriculture track still focused on production while the entrepreneurship track is biased towards non-agricultural products. We posit that a combined agricultural livelihood track would be an opportunity to introduce entrepreneurial skills instead of concentrating on the production aspect of farming and fishing, and that the entrepreneurship track should introduce the farm sector as an area for entrepreneurial activity.

At this point, it is too early to tell whether the livelihood track will produce the desired outcomes in the agriculture sector. There is still a question of drop-out rates due to poverty constraints. Another problem is that even in rural areas the mandated basic education calendar, does not conform with agriculture planting and harvesting cycles. Naturally, educational programs should take into account the agricultural cycle so as not to disrupt learning. Consequently, students might not even reach senior high school. To have more students engaged in agripreneurship, alternative learning systems must be introduced at the basic education level. A good model is the Family Farm School (FFS).

Family Farm Schools. The FFS educational concept originated in France in 1937. The Maison Familiales Rurales movement introduced the alternation concept, through which students learn in the classroom and in the farms on alternating schedules in order to enrich both theoretical and technical understanding of agriculture (Plougastel, n. d.). The Spanish educational system adapted the model in the 1960s, to lift up the lives of rural families, and the idea has spread to many other countries (Romana, 2012). In 1988, Pampamilyang Paaralang Agrikultura, Inc., a non-stock, nonprofit organization, established the first FFS in the Philippines. It drew the attention of other foundations and families and led to the formation of the Philippine Federation of Family Farm/Rural Schools, Inc. (Philfeffars).

The salient feature of the FFS is the alternancia or "sandwich" program, in which students spend one whole week in school and the next week or two in their farm homes. In the homes specially assigned tutors give them structured assignments that revolve around farm life. These tutors also visit them at their homes to offer valuesformation courses to the parents.

The Department of Education considers the FFS a "private special school" in the special secondary agriculture school category (Hernando-Malipot, 2012). As such, the FFS is able to offer courses not found in the national secondary curriculum. The alternation component of the program helps remedy the high absenteeism and dropout rate of regular schools that result when parents require their children to tend to the farm or the family enterprise rather than go to school (Claro, 2011). Since the farm or enterprise is now part of the program, there is no excuse not to complete the program. A student can already earn a living while studying.

The Philippine government has found merit in the unique offering of the FFS. Members of Congress and the Senate have recognized that the teaching strategy might revive interest in farming and repopulate rural communities, and approved in September 2013 a policy "establishing rural farm schools as alternative delivery mode of secondary education" (RA 10618, 2013). Under the law, each of the 80 provinces will establish one public rural farm school that will introduce farm entrepreneurship theory and practice in the last two years of high school.

The FFS is an alternative learning system for youngsters still in school. For those no longer in 
the school system, the Pilipinas Shell Foundation Inc. (PSFI) introduced the Sanayan sa Kakayahang Agrikultura (SAKA) project in the mid-1990s, which helps out-of-school youth to transition into agripreneurship. Similarly, the Management Association of the Philippines (MAP) has also introduced its version of the FFS, but this time catering to high school graduates who were unable to pursue higher education.

SAKA Program. Recognizing the need to support agriculture education, the PSFI originally designed a two-year, non-degree program for out-of-school youth that eventually became a one-year program. In the program, 70 percent of the time the students are in the field. Graduates of the SAKA program earn a certificate in farm management. The PSFI then helps them gain access to microcredit to implement their back-tofarm projects.

Habaradas (2012) presents many stories of how SAKA has influenced the lives of its graduates. For instance, Warlito Ligot, a native of Cagayan Valley, studied under the SAKA program supervised by Cavite State University in 1995. He immediately applied what he learned by setting up a modest farm. He was able to make his farm productive even when the entire province where his farm was located suffered from a drought. He learned he had to spread production risks so he engaged in a variety of farm activities. In 1999, the Department of Agriculture named him "Most Outstanding Young Farmer." Marinez SeracarpioDingcol, a 1998 SAKA scholar who studied at Pampanga Agricultural College, used a livelihood loan she availed herself of from the Land Bank of the Philippines upon her graduation to convert her father's idle farmland into an integrated animal-plant agricultural system. She quickly turned around her investment, earning enough to purchase her own farm. As she gained repute for her skills and knowledge, other farm owners invited her to manage their farms.

Farm Business Schools. The FBS uses the
FFS concept with slight variations in target market and delivery. Instead of providing an alternative high school, the FBS aims to teach agricultural entrepreneurship to out-of-school youth who have finished their secondary education, and who are not necessarily children of farmers. FBS students have a study-now, pay-later plan. The privately funded school led by the Meralco Foundation Inc. (MFI) is located on a 60-hectare farm, where students immediately apply what they learn (Morales, 2008). The MFI collaborates with the University of Rizal System, so that students who finish their coursework can continue to a college degree in entrepreneurial management (MFI, 2009).

The MFI expects students to spend one month in school and three months in a farm selected by the school, a cycle followed six times through the program. Thus, students receive exposure to six different farms in two years (R. Gayo, MFI executive director, personal communication, July 16, 2012). When in school, students learn management and entrepreneurship skills. After completing the program, the graduates either pursue further education in agriculture and manage small farms.

Young adults pursuing higher education generally prefer to enroll in programs that will lead to employment. The latest education report of the Philippine Statistics Authority reveals that 3.3 million students enrolled in tertiary education for academic year 2012-2013. The top five discipline groups with an aggregrate enrolment of 2.4 million students were business administration, education, engineering, information technology, and medicine. The discipline group of Agriculture, Forestry, Fisheries, and Veterinary Medicine had a total of 81,000 students. For the last eight years, enrollment for this group has been constant at two percent of the higher education population (PSA, 2015).

The low enrollment in the agricultural discipline group, despite its priority status, reflects a disinterest in pursuing a life in agriculture (Suarez, 2012). Packaged as a bachelor of science in agriculture program with an emphasis on crop 
production, it has been a course of study for those interested in research, and thus does not have general appeal.

The Commission on Higher Education approved the offering of a bachelor of science in entrepreneurship in 2005, and a bachelor of science in agribusiness in 2007. A review of the entrepreneurship program shows specialized subjects that hone some entrepreneurial skills, as well as one possible elective on Agricultural Entreprenuership, while the agribusiness degree offers agriculture and management courses, but no subjects on entrepreneurship. A gap still exists, because entrepreneurial activites in the agriculture sector require an appreciation of the cultivation side — a mastery of managerial responsibilities_as well as the skills and determination of an entrepreneurial mind. This gap can be addressed by the introduction of a bachelor of science in agricultural entrepreneurship. No Philippine university or college is offering this course. In the absence of such a degree, however, the Gawad Kalinga Foundation, a nongovernmental organization, has created an agriculture laboratory where university graduates are given opportunities to venture into agribusinesses.

Social Enterprise Model. The Gawad Kalinga Foundation (GK) is a nongovernment organization that sprang from a desire to help build community. It began with volunteers building houses for the poor and eventually evolved to include education, health, environment, and livelihood (Habaradas \& Aquino, 2010). In 2011, GK officially launched the GK Center for Social Innovation (CSI). Its target is to generate 500,000 social entrepreneurs who will create five million jobs in agriculture, technology, and tourism-ending poverty for five million—by 2024 (Meloto, 2011). GK launched the program in the GK Enchanted Farm, which serves as a business incubator for enterprises in agriculture. The 34-hectare farm in Angat, Bulacan, is the first of 24 such sites that the CSI hopes to establish in major provinces.

The three components of the GK Enchanted Farm are the university village for sustainable community development, "Silicon Valley" for social entrepreneurship, and "Disneyland" for social tourism (GK, 2014). For its first site, GK invited families to relocate to an unproductive farmland, where volunteers built their homes in an adjacent area. Then, GK invited young college graduates to start enterprise using the farmland produce as the main ingredients of their products or to employ the community members. In exchange, the entrepreneurs could sell their farm-processed goods in the village farm, which attracts thousands of local and foreign tourists weekly through various activities organized by GK. From the social innovation concept arose Bayani Brew, a brand of healthy drinks; Golden Duck, producer of turmeric-soaked salted duck eggs; Gourmet Keso, producer of artisan cheeses; Theo\&Philo Artisan Chocolates, producer of artisan chocolates; and Human Nature, producer of personal care products.

The CEO of GK, Antonio Meloto, claims that the GK Enchanted Farm is the first farm village university in the world (personal communication, August 20, 2012). Meloto, explained that the GK model uses its village farms as a live business incubator for budding entrepreneurs from middle-class families in urban areas. He targeted the middle-class because he believes they have more means to pursue entrepreneurial activities than the lower classes. He has personally convinced graduates of prestigious universities in the Philippines to invest in agriculture-related businesses.

The young entrepreneurs are required to follow fair-trade policies, and by doing so are able to market their produce as GK brands. As their businesses prosper, the communities they work with prosper as well. Meloto envisions that the community workers will develop entrepreneurial skills due to their exposure to the young entrepreneurs. Once they have saved enough, the community workers can start their own enterprises (Meloto, personal communication, August 20, 2012). Already, community workers have 
begun to venture into small home-based businesses (Dehesa, 2013).

To encourage the younger generation to take an interest in the agricultural sector, GK has started a campaign called "AgriCool" designed to show that agriculture is trendy (C. Atilano, GK entrepreneur, personal communication, August 20, 2012). Through this program, GK sponsors the education of 44 students taking undergraduate degrees in agriculture or agribusiness. Eventually, they will be able to use the GK farm as a business incubator.

A good deal of work still needs to be done to change mindsets. In August 2014, a group of young women with roots in the Philippines opened the School for Experiential and Entrepreneurial Development (SEED), a countryside college for social entrepreneurs. SEED aims to address the entrepreneurial skills shortage via practical and experiential rural-based education. Partly influenced by the GK model, US-born Leslie Espinosa convinced foreign-based friends Laurence Defontaines and Vicki Cabrera to join her in the mission in providing quality, practical education for those with the least opportunity, mostly children of subsistence farmers. They envision that this agrientrepreneurial school will produce 20,000 social entrepreneurs and innovators in the province of Bulacan, where the school is based. For two years, the initial group of 47 young scholars who reside near Gawad Kalinga, will be exposed to the various aspects of agriculture and enterepreneurship (Graham, 2014).

\section{Discussion and Implications}

Effective focus on building an entrepreneurial mindset among agriculturalists is still lacking. The usual response of governments to improve output in the agricultural sector is to invest in physical structures or to provide training for better farm productivity. These efforts are important but wasteful if not paired with a shift in mindset (Audinet \& Haralambous, 2005). Farmers need to become more equipped to help themselves so that they can rise above poverty (UNDP, 2008). Atchoarena and Gasperini (2003) conclude that educated farmers tend to be more productive since they are receptive to new technology. Research by Corbett (2005) indicates that prior knowledge, creativity and cognitive mechanisms contribute significantly to the process of opportunity identification and exploitation - the foundations of entrepreneurship. This supports the case not just for universal education, but also for education focused on the needs of farmers.

This commentary presented four models introduced by various sectors in Philippinne society. Each model is appropriate for particular groups, but the scale is too small and the length of program too short to expect any real impact in the immediate future. This means that the country does not expect to have a sudden upsurge of young, educated agripreneurs yet. The almost simultaneous introduction of these programs is gaining attention, however, and it is important to sustain the momentum.

The advantage of the family farm school is that it takes into account the farming cycle. When children of farmers are pulled out of school to help their parents during planting and harvesting time, these children are unable to complete their studies. Consequently, they fail to develop holistically and do not gain confidence about their abilities. The FFS alternative learning system, integrating farming operation with school activities, encourages continued classroom education of the children while inculcating in children a love for the farm. Combined with values education for both children and parents, this model helps build stronger family bonds, which supports the Filipino value of love for family. While there are only anecdotal accounts about how young students and graduates eventually pursued agriculture, the Philippine government has acknowledged that this applied farming education model is appropriate in rural areas and thus legislated the establishment of one public farm school in each of the 80 provinces in the country (RA 10618, 2013). Establishment of public farm schools will complement the 15 or so farm schools currently managed by the private sector.

The FFS is a farm school without a farm within the school premises, attracting children of farmers to study and live in the school compound during classroom sessions and return to their 
families on designated farm weeks (Bolido, 2014). The Farm Business School, on the other hand, is aimed at attracting out-of-school youth who do not necessarily belong to farming families. The students reside on the campus grounds, and rather than return to their families, learn about farming on the school's farm land. They also train for three straight months with agripreneurs who have partnered with the school. The immersion of students who have had no prior exposure to farming with agriprenurs who have transformed their farmland into highly profitable ventures, exposes these students to innovative farming practices and provides opportunities to become familiar with the value chain. This training with agripreneurs cycles six times through the curriculum.

Working as apprentices, these students learn from successful agripreneurs; it is hoped that this apprenticeship will translate into establishing their own farms. The Meralco Foundation Inc., proponent of the FBS, has yet to report officially on the status of its graduates; however, from a population of six students when it first opened in 2009, enrollment has risen to 200 .

Similar to FFS and FBS, the SAKA program integrates classroom learning with actual field work. Habaradas (2012) reported several success stories of graduates who started agriculture entrepreneurial ventures with funding support from financiers who had been tapped by the Pilipinas Shell Foundation, which manages SAKA. Upon finishing their SAKA education, these scholars are older than typical graduates from the FFS and FBS programs. This age difference could explain why the SAKA scholars are more likely to pursue agricultural ventures within a shorter time after graduation. For FFS and FBS graduates, it would appear that they would pursue advanced education in farm management or serve as apprentices while looking for opportunities.

The Social Enterprise Model of Gawad Kalinga is different from the first three in that the nonprofit organization targets fresh graduates from prominent schools in Manila and encourages them to pursue entrepreneurial activities within the organization's 34-hectare farm, called the farm village university. Because graduates from prominent schools are likely to come from well-to-do families, they generally have the means to start businesses quickly. The young entrepreneurs work within the existing farm community and help improve the income stream of the community. Through persistent observation and shared activities, the community workers learn from the entrepreneurs how to account for their time and resources, how to care for the quality of the produce, and how to deal with buyers. This gives them more confidence to begin businesses of their own. Meloto (personal communication, August 20, 2012) relates how some women have begun processing jams from organically grown produce and marketing these in the university village after observing how the young entrepreneurs conducted their operations.

The GK model works because the organization is highly credible. The organization is multiawarded and its founder, Antonio Meloto, is an internationally recognized social entrepreneur who has won several awards. He inspires young adults, investors, and government leaders to support his cause. He believes that it is possible to end poverty in the Philippines if the poor become more productive. Since many of the poor are located in rural areas, it makes sense to encourage entrepreneurship in agriculture.

The foregoing discussions clearly show that the Philippines is gaining headway in agripreneurship. Government officials and legislators are picking up from the initiatives of the private sector by enacting laws in support of agripreneurship education and developing programs in harmony with those mentioned in this paper. The Agricultural Training Institute (ATI) of the Department of Agriculture as well as the Technical Education and Skills Development Authority (TESDA) have redesigned some offerings to ensure that agricultural education takes into account the realities of the rythms of farm life (TESDA, 2011). The current approaches described show how cohort progression is improved by allowing students to spend time on farms and by involving the family in the education process.

Likewise, agripreneurship curriculum design addresses the gap in the skill set of existing agriculture programs. Opportunity seeking and opportunity screening aptitude, and development of 
enterprise and marketing skills, are required for agripreneurs to be able to create value on farms. Rather than for the government to focus on farm productivity, only to have depressed prices rendering a bumper crop useless, an education that hones the skills for spotting opportunities and looking towards value-creating products and services may be more sustaining. This specialized education becomes even more valuable as the Philippines opens its doors to Association of Southeast Asia Nations (ASEAN) economic integration. Since the Philippines is not likely to be price- competitive compared to Malaysia, Indonesia, Thailand, and Vietnam, which have economies of scale or efficient logistics chains, the country would be better off competing on the basis of product differentiation rather than farm productivity and of innovation rather than lower prices. This scenario can be achieved if Filipino farmers become more entrepreneurial.

\section{Conclusion}

Despite being a predominantly agriculture-based economy, the Philippines has become a net importer of agricultural goods. Part of the problem is the apparent disinterest to till the soil, largely because farming is not viewed as exciting and worthwhile. Previous education techniques have focused only on the technical aspects of agriculture. To enhance interest in agriculture, there is a need to invest not only in agriculture education, but also specifically in agricultural entrepreneurship education.

This commentary presents various ways of marrying agriculture and entrepreneurship as drawn from small pockets of nongovernment intervention in the Philippines. There is the FFS model for young children of farmers who attend classroom work and who can help their parents in their farms during pre-determined alternate periods. There is the FBS model for older out-ofschool youth who are trained in farms managed by successful agripreneurs, also with alternate classroom-field sessions. There is the SAKA model for even older adults, who earn an associate or full degree in agripreneurship and who may be more prepared to begin agricultural ventures. And there is the Social Enterprise Model, targeted at young graduates who can finance entrepreneurial businesses in the farm village university.

We believe that investing in agricultural entrepreneurship is one answer to the poverty gap that exists in agriculture-based communities where poor Filipinos are heavily represented. Farmers need to learn to become innovators and risk managers. They need to be more market-oriented and focused on adding value to produce rather than just farming and selling their produce at farm-gate prices. This is where education- not only for current farmers but also for next-generation agripreneurs-comes in.

Obviously, agripreneurs would need more than just skills to make a significant impact in far-flung agricultural communities. The government continues to invest in the farm-to-market roads, bridges, and nautical highways required for efficient and effective inter-island transfer of goods in an archipelago of 7,000 islands. These investments constitute the "hardware" needed to empower agripreneurs. The Department of Education and the Commission on Higher Education need to make available the "software" - the agripreneurship curriculum- to those Filipinos willing to stake their future in agricultural communities.

Poverty in the Philippines continues to be a rural phenomenon. While the desire of government to educate the rural poor and make them selfreliant is strong, the resources needed for such a program are wanting. Thus, the participation of civil service organizations and the private sector is a tremendous boost in this direction. There are many approaches to take, which are not mutually exclusive. What is clear is the goal of making the agricultural poor more productive by equipping them with entrepreneurial skills and making available financial resources to do so.

Finally, the various models presented were initiated by the private sector at different times. The FFS model has taken much more time to gain momentum than the GK model. Yet all four models seem to converge. It would be interesting for researchers to map the progress of each of these models and to assess their impact. The results of the FFS model can also be compared to its counterparts in France and Spain, where the 
program originated, and other countries, with the caveat that the agriculture sector in the country faces much more constraints and challenges than those in more developed countries. In the process, specific enabling and deterring factors can be determined.

\section{References}

Acs, Z., \& Szerb, L. (2007). Entrepreneurship, economic growth, and public policy. Small Business Economics, 28(2-3), 109-122. http://dx.doi.org/10.1007/ s11187-006-9012-3

Agricultural Market Information System. (2011). Enhancing market transparency. Rome: AMIS Secretariat. Retrieved from http://www.ifad.org/ english/market/amis.pdfhttp://www.ifad.org/ english/market/amis.pdf

Atchoarena, D., \& Gasperini, L. (2003). Education for rural development: Towards new policy responses. Rome: Food and Agriculture Organization of the United Nations, and Paris, France: UN Educational, Scientific and Cultural Organization. Retrieved from http://unesdoc.unesco.org/images/0013/ 001329/132994e.pdf

Audinet, J. P., \& Haralambous, S. (2005). Achieving the Millennium Development Goals: Rural investment and enabling policy. Rome: International Fund for Agricultural Development. Retrieved from http://www.ifad.org/events/gc/28/panel/e.pdf

Bolido, L. (2014, February 11). The farm school without a farm. The Philippine Daily Inquirer. Retrieved from http://newsinfo.inquirer.net/576450/the-farmschool-without-a-farm

Bordey, F., \& Litonjua, A. (2013). Curing the cause rather than the symptom: The case of rice smuggling. Rice Science for Decision Makers, 4(1).

Busenitz, L., Gomez, C., \& Spencer, J. (2000). Country institutional profiles: Unlocking entrepreneurial phenomena. Academy of Management Journal, 43(5), 994-1003. http://dx.doi.org/10/2307/1556423

Cai, O. (2013, March 21). PH may continue rice imports after 2013. Rappler. Retrieved from http://www.rappler.com/business/industries/247agriculture/24331-ph-may-continue-rice-importsafter-2013

Cariño, C. (2013, June 22). Aging Filipino farmers to affect food security. Manila Times. Retrieved from http://www.manilatimes.net/aging-filipino- farmers-to-affect-food-security/12166/

Carroll, N. (2010, January). Microfinance in the Philippines. Asia Focus. Retrieved from http://www.frbsf.org/banking-supervision/ publications/asia-focus/2010/january/ microfinance-philippines/january.pdf

Casauay, A. (2014, May 22). PH farmers endangered specials. Rappler. Retrieved from http://www.rappler.com/business/specialreport/world-economic-forum/2014/58607-phfarmers-endangered-species-pangilinan

Claro, J. (2011, June 8). Learning is fun in family farm schools. Philippine Star. Retrieved from http://www.philstar.com/Article.aspx?articleId=69 3630\&publicationSubCategoryId $=80$

Corbett, A. (2005). Experiential learning within the process of opportunity identification and exploitation. Entrepreneurship Theory and Practice, 29(4), 473-491.

Dehesa, T. (2013). The journey out of poverty. Mandaluyong City, Philippines: Gawad Kalinga Community Development Foundation. Retrieved from http://www.gk1world.com/journey-out-of-poverty

Fernandez-San Valentin, C., \& Berja, J. (2012). Philippine food and nutrition security atlas. Makati City, Philippines: World Food Programme-Philippines. Retrieved from http://documents.wfp.org/stellent Lgroups/public/documents/ena/wfp246455.pdf

Gawad Kalinga. (2014). About the Gawad Kalinga Enchanted Forest. Mandaluyong City, Philippines: Author. Retrieved from http://www.gk1world.com/gk-enchanted-farm

Graham, T. (2014, September 14). Chasing the Filipino dream. The Philippine Star. Retrieved from http://www.philstar.com/headlines/2014/09/14/ $1368909 /$ chasing-filipino-dream

Habaradas, R. \& Aquino, M. (2010). Gawad Kalinga: Innovation in the city (and beyond) (Working Paper Series 2010-01C). Manila: De La Salle UniversityAngelo King Institute. Retrieved from http://gk1world.com/innovation-in-thecity- $\% 28$ and-beyond $\% 29$

Habaradas, R. (2012). Corporate social initiatives in the Philippines: The experiences of two corporate foundations (Unpublished doctoral dissertation). Organization and Management Department, De La Salle University, Manila, Philippines. 
Hernando-Malipot, I. (2012, June 3). School merges farm and classroom. Manila Bulletin. Retrieved from http://mb.com.ph/articles/361073/schoolmerges-farm-and-classroom

Hull, K. (2009). Understanding the relationship between economic growth, employment and poverty reduction. In Organisation for Economic Cooperation and Development (Ed.), Promoting pro-poor growth: employment (pp. 69-93). Paris: OECD Press. Retrieved from http://www.oecd.org/dac/ povertyreduction/43514554.pdf

Islam, R. (2004). The nexus of economic growth, employment and poverty reduction: An empirical analysis (Discussion Paper 14). Geneva: International Labour Office. Retrieved from http://ilo.int/wcmsp5/groups/ public/---ed emp/documents/publication/ wcms 120690.pdf

Kahan, D. (2007). Farm management extension services: $A$ review of global experience (Occasional Paper 21). Rome: Food and Agricutural Organization of the UN. Retrieved from ftp://ftp.fao.org/docrep/ fao/010/a1494e/a1494e00.pdf

Karnani, A. (2007). Misfortune at the bottom of the pyramid. Greener Management International, 51, 99110.

Knudson, W., Wysocki, A., Champagne, J., \& Peterson, H. C. (2004). Entrepreneurship and innovation in the agri-food system. American Journal of Agricultural Economics, 86(5), 1330-1336. http://dx.doi.org/ 10.1111/j.0002-9092.2004.00685.x

Lamb, W., \& Sherman, H. (2010). Developing highgrowth businesses in rural areas: A study of four US states. New England Journal of Entrepreneurship, 13(2), 9-19.

Martin, K. (2014, July 20). Banks' agra loans still below law's mandate. The Philippine Star. Retrieved from http://www.philstar.com/business/2014/07/20/1 348130/banks-agra-loans-still-below-laws-mandate

McElwee, G., \& Annibal, I. (2009). Business support for farmers: A necessary evil? International Journal of Rural Management, 5(2), 175-195. http://dx.doi.org/10.1177/097300521000500203

Meloto, T. (2011). P-Noy at the GK Enchanted Farm. Mandaluyong City, Philippines: Gawad Kalinga Community Development Foundation. Retrieved from http://gk1world.com/p-noy-at-the-gkenchanted-farm

Mendoza, R. (2011). Why do the poor pay more?
Exploring the poverty penalty concept. Journal of International Development, 23(1), 1-28.

Meralco Foundation Inc. (2009). MFI-FBI partners with URS and MAP for ladderized farm business curriculum. Manila: MFI. Retrieved from http://www.mfi.org. $\mathrm{ph} /$ news/mfi-fbi-partners- urs-map-ladderizedfarm-business-curriculum/

Morales, N. J. (2008, September 11). Farm school to teach entrepreneurship. Manila: GMA Network. Retrieved from http://www.gmanetwork.com/ news/story/119502/news/nation/farm-school-toteach-entrepreneurship

National Economic and Development Authority. (2011). Philippine development plan 2011-2016. Pasig City, Philippines: Author. Retrieved from http://www.neda.gov.ph/wp-content/uploads/ 2013/10/pdprm2011-2016.pdf

O’Neill, G., Hershauer, J., \& Golden, J. (2009). The cultural context of sustainability entrepreneurship. Greener Management International, 55, 33-46.

Okabe, M. (2013). Where does Philippine education go? The 'K-to-12' program and reform of the Philippine basic education system (Discussion Paper 425). Chiba City, Japan: Institute of Developing Economies. Retrieved from http://www.ide.go.jp/English/ Publish/Download/Dp/pdf/425.pdf

Philippine Statistics Authority [PSA]. (2013). Selected statistics on agriculture 2013. Quezon City, Philippines: PSA. Retrieved from http://www.bas.gov.ph/?ids= downloads view\&id $=653$

PSA. (2015). Higher education enrolment in government and private schools by discipline group. Quezon City, Philippines: PSA. Retrieved from http://www.nscb.gov.ph/secstat/d educ.asp

Plougastel, V. K. (n. d.). The MFR in France and in the world. Paris: Union Nationale des Maisons Familiales Rurales. Retrieved from http://www.mfr.asso.fr/mfr-dans-le-monde/ Documents/presentation-des-MFR-en-anglais.pdf

Republic Act 10618. (2013). Rural Farm Schools Act. Manila: Official Gazette of the Republic of the Philippines. Retrieved from http://www.gov.ph/ 2013/09/03/republic-act-no-10618/

Richards, S., \& Bulkley, S. (2007). Agricultural entrepreneurs: The first and the forgotten? (Hudson Institute: Enterpreneurship Research Paper Series 07-01). Washington, D.C.: Hudson Institute. http://dx.doi.org/10.2139/ssrn.1020697 
Romano. (2012). Family farm schools: An effective formation for finding a first job. Romana: Bulletin of the Prelature of the Holy Cross. Rome: Prelature of the Holy Cross and Opus Dei. Retrieved from http://en.romana.org/art/54 6.01

Rosero, E.V. (2013, March 17). Ranks of underemployed plus jobless Pinoys swell to $10.8 \mathrm{M}$ - NSO survey. Manilla: GMA Network. Retrieved from http://www.gmanetwork.com/news/story/ 299663/economy/business/ranks-of-underemploy ed-plusjobless-pinoys-swell-to-10-8m-nso-survey

Santiago, A. (2014, August 4). From farmer to agripreneurs. Manila Times Online. Retrieved from http://www.manilatimes.net/farmer-agripreneurs/ $116435 /$

Singh, A., \& Krishna, K. V. S. M. (1994). Entrepreneurship and agricultural development. Journal of Entrepreneurship, 3(1), 97-111.

Suarez, K.D. (2012). 'Unpopular' courses the road less travelled. Rappler. Retrieved from http://www.rappler.com/nation/7394-the-lesspopular-route

Tacoli, C. (2011). Links between rural and urban development in Africa and Asia. In UN Department of Economic and Social Affairs: Population Division (Ed.), Population distribution, urbanization, internal migration and development: $A n$ international perspective (pp. 110-122). New York: UN DESA.

Technical Education and Skills Development Authority (2011). Investing in the $21^{\text {st }}$ century skilled Filipino workforce. Taguig, Philippines: Author. Retrieved from http://www.tesda.gov.ph/uploads/File/ LMIR2011/july2012/NTESDP\%20Final\%20asofS ept12.pdf

Timmer, C.P. (2005). Agriculture and pro-poor growth: An Asian perspective (Working Paper 63). Washington,
D.C.: Center for Global Development. Retrieved from http://www.cgdev.org/files/2986 file WP63 1.pdf

United Nations General Assembly. (2013). A life of dignity for all: Accelerating progress towards the millennium development goals and advancing the United Nations development agenda beyond 2015. New York: Report of the Director-General, Sixty-Eighth Session, UN. Retrieved from http://www.un.org/millennium goals $/$ pdf $/ \mathrm{A} \% 20$ Life $\% 20$ of $\% 20$ Dignity $\% 20$ for $\% 2$ 0All.pdf

United Nations Development Programme. (2008). Creating value for all: Strategies for doing business with the poor. Executive summary. New York: Author. Retrieved from http://www.undp.org/content Ldam/rwanda/docs/povred/RW rp Creating Val ue for All Doing Business with the Poor.pdf

Vallianatos, M., Gottlieb, R., \& Haase, M.A. (2004). Farm-to-school: Strategies for urban health, combating sprawl, and establishing a community food systems approach. Journal of Planning Education and Research, 23(4), 414-423. http://dx.doi.org/10.1177/0739456X04264765 van Stel, A., Carree, M., \& Thurik, R. (2005). The effect of entrepreneurial activity on national economic growth. Small Business Economics, 24(3), 311-321.

von Braun, J., \& Diaz-Bonilla, E. (2008). Globalization of food and agriculture and the poor (Issue Brief 52).

Washington, D.C.: International Food Policy

Research Institute. Retrieved from http://www.ifpri.org/sites/default/files/ publications/ib52.pdf

Williams, L., \& McGuire, S. (2010). Economic creativity and innovation implementation: The entrepreneurial drivers of growth? Evidence from 63 countries. Small Business Economics, 34(4), 391412. http://dx.doi.org/10.1007/s11187-008-9145-7 